DOI: $10.31393 /$ reports-vnmedical-2021-25(1)-16

UDC: $618.3-008: 615.837 .3: 576$

\title{
USING PENTOXIFYLLINE, ARGININE HYDROCHLORIDE, LEVOCARNITINE AND RHEOSORBILACT SOLUTIONS FOR CORRECTION OF FETOPLACENTAL DYSFUNCTION IN PREGNANT WOMEN WITH PREECLAMPSIA
}

Horbatiuk 0. ${ }^{1}$, Hryhorenko A. ${ }^{1}$, Shatkovska A. ${ }^{1}$, Binkovska A. ${ }^{1}$, Vaskiv $0 .{ }^{1}$, Herych $0 .{ }^{1}$, Garbuziuk V. ${ }^{1}$, Ropotan . $^{2}$

${ }^{1}$ National Pirogov Memorial Medical University, Vinnytsya (Pyrogov str., 56, Vinnytsya, Ukraine, 21018),

${ }^{2}$ City Prenatal Center (Hotovytsky str., 6, Khmelnytsky, Ukraine, 29016)

Responsible for correspondence: e-mail: gynecology_fpo@vnmu.edu.ua

Received: December 29, 2020; Accepted: February 01, 2021

Annotation. As of today, there is no effective method for treating the fetoplacental dysfunction (FPD) in pregnant women with preeclampsia. The aim of research was the study of the method proposed by the authors for restoring the functional activity of the fetoplacental complex in pregnant women with FPD on the background of treatment of preeclampsia. A randomized controlled study of the effect proposed treatment (intravenous solution of pentoxifylline; solution containing arginine hydrochloride and levocarnitine; rheosorbilact) of 37 pregnant women at 35-40 weeks of gestation with FPD on the background of moderate preeclampsia, was performed. Such ultrasound doppler measurements have been studied: systolic-diastolic ratio, resistance index, pulsation index in the umbilical arteries, right and left uterine arteries, fetal middle cerebral artery, fetal internal carotid artery and fetal aorta before and after the performed treatment. Statistics were processed using LibreOffice Calc (Mozilla Public License v 2.0), adapted for medical and biological research. We used nonparametric Wilcoxon criteria, Mann-Whitney criteria at a significance level of $p<0.05$. After the performed treatment, stabilization of the fetoplacental blood circulation in women of the main group was observed, which manifested by decrease in $S / D$ in umbilical artery in 1.3 times, in the left uterine artery in 1.4 times and in the fetal aorta in 1,1 times, and decrease in Rl indices in the umbilical artery in 1.1 times, in the right uterine artery in 1.3 times, and increase in the middle cerebral artery in 1.4 times. So, in the course of the proposed treatment, the restoration of the blood flow velocity and the stabilization of vascular resistance in uterine arteries and the umbilical artery were observed in the women of the main group. The research of the possibility of using the above methodology in earlier gestational age and in the risk group for the prevention of preeclampsia is prospective and requires further attention.

Keywords: fetoplacental dysfunction, preeclampsia, optimization of treatment.

\section{Introduction}

FPD is based on the malfunction of the compensatory and adaptive mechanisms of the fetoplacental unit at the molecular, cellular and tissue levels. FPD accompanies almost all complications of pregnancy. Its frequency in patients with preeclampsia makes up on average $66.3 \%$ $[22,23]$.

Antiadrenergic drugs with the central mechanism of action (methyldopa) or $\beta$-blockers (labetalol) are usually used for the treatment of preeclampsia. Though, these drugs slow down the blood microcirculation in the placenta, causing or exacerbating the fetoplacental dysfunction $[8,18]$.

As of today, there is no method for treating the FPD in pregnant women with preeclampsia, which would significantly improve the condition of the fetus and prevent the aging of the placenta and, respectively, its malfunction. Methods of correction of the FPD in pregnant women are at the research stage, do not give the guaranteed effect, and require further intensive study and improvement.

Since the FPD has a certain pathomorphological basis, which is manifested by the narrowing of the spiral arterioles and capillaries in the placental area, in which areas of stasis, aggregation and adhesion of the formed elements appear $[5,15,22]$, and in the treatment of preeclampsia with Dopegit or Labetalol this situation is accompanied by a slowdown in the blood flow in placental vessels $[5,7,15,18]$, our task was to study drugs that would eliminate these phenomena and be safe for the fetus.

Aim of the research was the development and research of the method for restoring the functional activity of the fetoplacental unit in pregnant women with FPD on the background of treatment of preeclampsia.

The set task is carried out by using intravenous solution of pentoxifylline $0.05 \%-100 \mathrm{ml}$; solution containing arginine hydrochloride $4.2 \%$ and levocarnitine $2.0 \%-100 \mathrm{ml}$; rheosorbilact - $100 \mathrm{ml}$ once a day, in the specified sequence, 10 infusions per course of treatment [7].

Pentoxifylline is a peripheral vasodilator from the purine group. According to the modern scientific evidence [12], Pentoxifylline increases erythrocyte flexibility, fibrinolytic and tissue plasminogen activator activity and inhibits platelet adhesion. Importantly, its action on platelets does not increase platelet adhesion or impair their function [13, 25].

Pentoxifylline improves the blood microcirculation in areas of the impaired blood supply and normalizes the rheological properties of blood, causes vasodilation, and reduces the total peripheral vascular resistance. The drug relaxes the smooth muscles of arteries, increases the delivery of oxygen to the peripheral organs. The drug 
improves the blood oxygenation by widening the blood vessels of lungs. It reduces blood viscosity, causes platelet disaggregation, and increases the elasticity of red blood cells by affecting the properties of the red blood cell membrane $[24,25]$. The use of pentoxifylline in this situation was "off label", but availability the large number of reports of its successful use during pregnancy [12, 13, 24, 25], we also included it in the proposed treatment regimen, since it complements and enhances the action of arginine and rheosorbilact.

Arginine hydrochloride has antihypoxic, membranestabilising, cytoprotective, antioxidant, detoxification activity, acts as an active regulator of the intermediate metabolism and energy supply processes, plays a significant role in maintaining the hormonal balance in the body. In addition, arginine hydrochloride is a substrate for No-synthase, the enzyme that catalyzes the synthesis of nitric oxide in endotheliocytes $[13,14,16]$. Levocarnitine is necessary for transferring long-chain fatty acids to mitochondria for their subsequent $\beta$-oxidation and energy formation [7].

The infusion therapy includes rheosorbilact intravenous solution - $100 \mathrm{ml}$, which contains sorbitol, sodium lactate, sodium chloride, calcium chloride, potassium chloride, magnesium chloride. Rheosorbilact has a rheological, antishock, detoxification, rehydration, and alkalizing effect, improves tissue microcirculation and perfusion, which is especially important in FPD, facilitates the correction of metabolic acidosis, increases the body's resistance to infections [3, 4].

Thus, pentoxifylline in combination with arginine hydrochloride, levocarnitine and rheosorbilact solution facilitates the oxygen saturation of blood, the restoration of nitric oxide synthesis in endothelial and placental cells, the improvement of rheology and microcirculation of blood through the placenta, removes the vasoconstrictive effect from vessels of the fetoplacental unit, has the antihypoxic impact on the fetus, facilitates the general detoxification of the woman's body [7].

\section{Materials and methods}

72 pregnant women at 35-40 weeks of pregnancy with moderate preeclampsia and signs of FPD were under our supervision. They were randomized into two groups. 37 of them (MG - main group) received, in addition to the antihypertensive therapy, the intravenous solution of pentoxifylline $100 \mathrm{ml}$, solution containing arginine hydrochloride $4.2 \%$ and levocarnitine $2.0 \%-100 \mathrm{ml}$ and rheosorbilact - $100 \mathrm{ml}$ once a day, in the specified sequence, 10 infusions per course of treatment [7]. The remaining 35 women (CG - comparison group) received only the antihypertensive therapy (methyldopa, labetalol).

The control group consisted of 32 pregnant women at 35-40 weeks of gestation with a normal course of pregnancy.

Only those women with preeclampsia who took Dopegit or Labetalol antihypertensive drugs for at least 10 days were selected for the study.
The average age of pregnant women in the main group was $26.4 \pm 5.2$ years, in the comparison group - $25.5 \pm 6.1$ years, and in the control group $-24.3 \pm 3$.3 years. Women of all groups were pregnant with 1 fetus. Before treatment, the blood pressure (BP) in the main group was: $158 \pm 15.8 /$

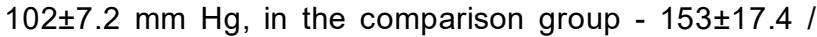
$101 \pm 8.3 \mathrm{~mm} \mathrm{Hg}$, in the control group - $115 \pm 9.2 / 75 \pm 5.8 \mathrm{~mm}$ $\mathrm{Hg}$. The edema of the upper, lower extremities and anterior abdominal wall was observed in $28(75.7 \%)$ pregnant women of the MG and in 25 (71.4\%) women of the CG. The edema of lower extremities was recorded in $21.9 \%$ of the pregnant women in the control group. The daily proteinuria in the main group made up $1.39 \pm 0.81 \mathrm{~g} / \mathrm{l}$, in the comparison group - $1.41 \pm 0.76 \mathrm{~g} / \mathrm{l}$, and in the control group - $0.033 \pm 0.06$ $\mathrm{g} / \mathrm{l}$. The main group and the comparison group were comparable according to indices of pressure, edema, and daily proteinuria. The significant difference $(p<0.05)$ of these two groups was observed against the indices of the control group.

Pregnant women of the main and comparison groups underwent the Doppler indices study [9, 21]: S/D (systolicdiastolic ratio), RI (resistance index), $\mathrm{PI}$ (pulsation index) in the umbilical arteries, right and left uterine arteries, fetal middle cerebral artery, fetal internal carotid artery and fetal aorta before and after the performed treatment. Pregnant women of the control group also underwent the Doppler study twice, with the interval of 10 days. Dopplerometry was performed using Voluson S8 device manufactured by General Electric (USA), using C1-5-RS convex transducers operating in $3.5 \mathrm{MHz}$ range in color and pulse Doppler mode.

Pregnant women with preeclampsia, from whom, according to the results of the Doppler study, zero or reverse blood flow was registered in umbilical arteries or the fetal aorta, were not included in the study.

Statistic data were processed by means of LibreOffice Calc (Mozilla Public License v 2.0) adapted for medical and biological research. Wilcoxon non-parametric criteria for even samples were used for comparison of quantitative data before and after the treatment period. When the difference was found, paired comparisons of groups by means of MannWhitney criteria were used. Differences were recognized reliable when the level of significance was $p<0.05$ [11].

Ethical approval. An examination of women of all groups was carried out in Khmelnytsky municipal perinatal center from 1.09.2018 till 31.08.2020 year. The written agreement with the women who volunteered to participate in the research was signed. Approval National Pirogov Memorial Medical University, Vinnytsya Ethics Committee was Received. Permission for publishing of materials: the protocol № 3, from 03.12.2020.

\section{Results}

Before starting treatment with intravenous solution of pentoxifylline, arginine hydrochloride, levocarnitine and rheosorbilact, the pregnant women with preeclampsia underwent a Doppler examination (Table 1). 
Thus, before treatment, the main group, as well as the comparison group of women differed from the control group by 9 out of 18 studied parameters of dopplerometry. In particular, the attention is drawn to the fact that significant differences $(p<0.05)$ against all the indices in comparison with the control group were observed in the umbilical artery in women with preeclampsia of both groups. In addition, the blood velocity in uterine arteries in women with preeclampsia significantly $(p<0.05)$ differed from the control group by $\mathrm{RI}$ and $\mathrm{PI}$ indices in the right uterine artery, by $\mathrm{S} / \mathrm{D}$ and $\mathrm{PI}$ indices in the left uterine artery. The middle cerebral artery in women under study differed from the control group only by RI index, and the fetal aorta by S/D index, which indicates that the fetus is still in relatively satisfactory condition in this pathology.

After the performed treatment in the main group of women, the significant difference $(p<0.05)$ against the control group was revealed by 3 indices out of 18 , whereas in the comparison group - by 9 (Table 2).

Table 1. The Doppler indices in women with preeclampsia before treatment.

\begin{tabular}{|c|c|c|c|}
\hline \multirow[b]{2}{*}{ Indices } & \multicolumn{3}{|c|}{ Groups of examined women } \\
\hline & $\begin{array}{l}\text { Main group } \\
\quad \mathrm{n}=37\end{array}$ & $\begin{array}{c}\text { Comparison group } \\
\mathrm{n}=35\end{array}$ & $\begin{array}{c}\text { Control group } \\
n=32\end{array}$ \\
\hline \multicolumn{4}{|c|}{ The umbilical artery } \\
\hline$S / D$ & $3,93 \pm 0,76$ * & $3,96 \pm 0,81$ * & $2,75 \pm 0,36$ \\
\hline RI & $0,70 \pm 0,06^{*}$ & $0,69 \pm 0,09$ * & $0,51 \pm 0,07$ \\
\hline PI & $1,10 \pm 0,08$ * & $1,09 \pm 0,11$ * & $0,81 \pm 0,08$ \\
\hline \multicolumn{4}{|c|}{ Right uterine artery } \\
\hline$S / D$ & $2,23 \pm 0,44$ & $2,32 \pm 0,51$ & $1,79 \pm 0,17$ \\
\hline RI & $0,86 \pm 0,13$ * & $0,91 \pm 0,12$ * & $0,58 \pm 0,09$ \\
\hline PI & $1,56 \pm 0,13$ * & $1,62 \pm 0,18$ * & $1,32 \pm 0,06$ \\
\hline \multicolumn{4}{|c|}{ Left uterine artery } \\
\hline$S / D$ & $2,87 \pm 0,16$ * & $2,83 \pm 0,13$ * & $1,73 \pm 0,11$ \\
\hline RI & $0,61 \pm 0,11$ & $0,60 \pm 0,10$ & $0,43 \pm 0,09$ \\
\hline $\mathrm{PI}$ & $1,89 \pm 0,06$ * & $1,86 \pm 0,05$ * & $1,31 \pm 0,04$ \\
\hline \multicolumn{4}{|c|}{ The middle cerebral artery } \\
\hline S/D & $4,91 \pm 0,46$ & $4,85 \pm 0,32$ & $4,25 \pm 0,38$ \\
\hline RI & $0,51 \pm 0,19$ * & $0,50 \pm 0,21$ * & $0,92 \pm 0,20$ \\
\hline PI & $1,52 \pm 0,16$ & $1,58 \pm 0,12$ & $1,65 \pm 0,19$ \\
\hline \multicolumn{4}{|c|}{ Internal carotid artery } \\
\hline S/D & $4,80 \pm 0,43$ & $4,72 \pm 0,36$ & $4,1 \pm 0,31$ \\
\hline RI & $0,48 \pm 0,18$ & $0,41 \pm 0,19$ & $0,72 \pm 0,16$ \\
\hline $\mathrm{PI}$ & $1,35 \pm 0,24$ & $1,41 \pm 0,26$ & $1,38 \pm 0,22$ \\
\hline \multicolumn{4}{|c|}{ The fetal aorta } \\
\hline S/D & $6,64 \pm 0,68$ * & $6,81 \pm 0,72$ * & $5,22 \pm 0,69$ \\
\hline RI & $0,83 \pm 0,07$ & $0,86 \pm 0,09$ & $0,76 \pm 0,04$ \\
\hline PI & $1,98 \pm 0,13$ & $2,03 \pm 0,15$ & $1,82 \pm 0,07$ \\
\hline
\end{tabular}

Note. ${ }^{*}$ - the difference is significant against the indices of the control group $(p<0.05)$.
That is, the restoration of 6 Doppler indices was observed in the group of pregnant women who received the proposed therapy, which after treatment did not significantly differ $(p>0.05)$ from the group of healthy pregnant women. The decrease of $S / D$ in umbilical artery in 1.3 times, in the left uterine artery in 1.4 times and in the fetal aorta in 1,1 times, as well as decrease of RI indices in the umbilical artery in 1.1 times, in the right uterine artery in 1.3 times, and increase in the middle cerebral artery in 1.4 times were observed in women of the main group.

Thanks to the proposed treatment in women with preeclampsia, it was possible to prolong pregnancy until the term of delivery and to achieve a good assessment of the newborn on the Apgar scale. The term of delivery in the main group was $38.3 \pm 1.4$ weeks and did not differ significantly $(p>0.05)$ from the control group - 39.8 \pm 0.6 weeks. In the comparison group the term of delivery $37.2 \pm 1.7$ weeks was significant $(p<0.05)$ less than in the control group.

Table 2. The Doppler indices in women with preeclampsia after treatment.

\begin{tabular}{|c|c|c|c|}
\hline \multirow[b]{2}{*}{ Indices } & \multicolumn{3}{|c|}{ Groups of examined women } \\
\hline & $\begin{array}{c}\text { Main group } \\
\mathrm{n}=37\end{array}$ & $\begin{array}{c}\text { Comparison group } \\
\mathrm{n}=35\end{array}$ & $\begin{array}{c}\text { Control group } \\
n=32\end{array}$ \\
\hline \multicolumn{4}{|c|}{ The umbilical artery } \\
\hline$S / D$ & $3,03 \pm 0,64$ & $4,02 \pm 0,76$ * & $2,70 \pm 0,28$ \\
\hline $\mathrm{RI}$ & $0,64 \pm 0,13$ & $0,72 \pm 0,11$ * & $0,49 \pm 0,08$ \\
\hline $\mathrm{PI}$ & $0,99 \pm 0,08$ * & $1,23 \pm 0,16$ * & $0,79 \pm 0,09$ \\
\hline \multicolumn{4}{|c|}{ Right uterine artery } \\
\hline$S / D$ & $2,03 \pm 0,28$ & $2,38 \pm 0,66$ & $1,80 \pm 0,14$ \\
\hline $\mathrm{RI}$ & $0,67 \pm 0,2$ & $0,80 \pm 0,19$ & $0,52 \pm 0,11$ \\
\hline $\mathrm{PI}$ & $1,76 \pm 0,19$ * & $1,88 \pm 0,21$ * & $1,41 \pm 0,12$ \\
\hline \multicolumn{4}{|c|}{ Left uterine artery } \\
\hline$S / D$ & $2,06 \pm 0,19$ & $2,86 \pm 0,21^{*}$ & $1,79 \pm 0,13$ \\
\hline$\overline{\mathrm{RI}}$ & $0,62 \pm 0,16$ & $0,89 \pm 0,19$ * & $0,51 \pm 0,10$ \\
\hline $\mathrm{PI}$ & $1,49 \pm 0,16$ * & $1,41 \pm 0,12$ & $1,22 \pm 0,09$ \\
\hline \multicolumn{4}{|c|}{ The middle cerebral artery } \\
\hline$S / D$ & $4,82 \pm 0,40$ & $5,07 \pm 0,36$ * & $4,15 \pm 0,33$ \\
\hline $\mathrm{RI}$ & $0,72 \pm 0,23$ & $0,47 \pm 0,20$ * & $0,88 \pm 0,18$ \\
\hline $\mathrm{PI}$ & $1,52 \pm 0,16$ & $1,58 \pm 0,12$ & $1,72 \pm 0,15$ \\
\hline \multicolumn{4}{|c|}{ Internal carotid artery } \\
\hline$S / D$ & $4,11 \pm 0,36$ & $4,70 \pm 0,31$ & $3,9 \pm 0,27$ \\
\hline $\mathrm{RI}$ & $0,59 \pm 0,23$ & $0,43 \pm 0,22$ & $0,68 \pm 0,19$ \\
\hline $\mathrm{PI}$ & $1,33 \pm 0,24$ & $1,40 \pm 0,25$ & $1,34 \pm 0,27$ \\
\hline \multicolumn{4}{|c|}{ The fetal aorta } \\
\hline$S / D$ & $6,14 \pm 0,39$ & $7,02 \pm 0,61$ * & $5,34 \pm 0,51$ \\
\hline $\mathrm{RI}$ & $0,81 \pm 0,11$ & $0,89 \pm 0,10$ & $0,79 \pm 0,08$ \\
\hline $\mathrm{PI}$ & $1,95 \pm 0,19$ & $2,13 \pm 0,18$ & $1,99 \pm 0,12$ \\
\hline
\end{tabular}

Note. ${ }^{*}$ - the difference is significant against the indices of the control group $(p<0.05)$. 
The assessment of newborns on the Apgar scale in the main group was $6.8 \pm 0.7$ points and did not differ significantly ( $p>0.05)$ from the control group - $7.7 \pm 0.5$ points. In the comparison group, the assessment of newborns on the Apgar scale was $5.7 \pm 1.3$ points, and was significantly lower than in the control group $(p<0.05)$.

\section{Discussion}

In the course of dopplerometry for women with preeclampsia on the background of antihypertensive drugs intake (before the prescription of intravenous solution of pentoxifylline, arginine hydrochloride, levocarnitine and rheosorbilact), the attention was drawn to the significant slowdown in the blood flow and the increase of the vascular resistance in umbilical and uterine arteries, as evidenced by significantly $(p<0.05)$ increased $S / D, R I$ and $P I$ indices in these structures, which coincides with the data of other researchers $[1,2,5,17,21]$. Such increases in the numerical values of S/D, RI and $\mathrm{PI}$ in the uterine arteries are regarded by clinicians as early signs of preeclampsia [9, 10, 21, 22]. This may be due to the insufficient invasion of the trophoblast into spiral arteries, which leads to the significant increase of vascular resistance of the maternal part of the placenta and the impaired development of fetoplacental vessels due to the obliteration of tertiary arterioles of the villi $[20,21,26]$.

The malfunction of Doppler indices in the fetal umbilical arteries, which is manifested by the increase of the vascular resistance to the blood flow, is the manifestation of the fetoplacental dysfunction, and it indicates not only the pathology of blood circulation in the placenta, but also the process of decompensation of the fetal life support [1, 18, $19,20]$. The significant decrease of $\mathrm{RI}$ in the fetal middle cerebral artery revealed before treatment in women with preeclampsia of both groups may be a compensatory reaction to the deterioration of the fetoplacental blood circulation and is the indirect sign of brain plethora (the phenomenon of blood circulation centralization) $[1,9,10$, 20]. Attempts to improve the utero-placental blood circulation in fetoplacental dysfunction using arginine are described in the scientific literature [2, 14, 17]. By adding pentoxifylline and rheosorbilact to arginine (according to our method), we not only dilate blood vessels of the microcirculatory bloodstream, but also improve its oxygenation and detoxification $[3,7,13,23]$. We used pentoxifylline to enhance the action of L-arginine, and rheosorbilact to gently remove toxins from the feto-placental complex [7, 12, 24, 25]. Such a treatment regimen allows to restore the functional activity of the fetoplacental complex much faster than just L-arginine.

The proposed treatment significantly improved Doppler indices in women of the MG (6 out of 9 indices returned to the level of control group), despite the long-term intake of

\section{References}

[1] Aljunaidy, M. M., Morton, J. S., Cooke, C. M., \& Davidge, S. T. (2017). Prenatal hypoxia and placental oxidative stress: linkages to developmental origins of cardiovascular disease. American Journal of Physiology-Regulatory, Integrative and dopegit and labetalol.

As for women with preeclampsia who received only the antihypertensive therapy (CG), the situation did not change against the control group. Doppler indices in the CG, which significantly $(p<0.05)$ differ from the control group (9 out of 18 ), indicate the progression of the fetoplacental dysfunction in the course of the long-term intake of antihypertensive drugs.

The use of pentoxifylline $0.05 \%-100 \mathrm{ml}$; solution containing arginine hydrochloride $4.2 \%$ and levocarnitine $2.0 \%$ - $100 \mathrm{ml}$; rheosorbilact - $100 \mathrm{ml}$ intravenously once a day, in the specified sequence, 10 infusions per course of treatment allows to improve the functional activity of the fetoplacental unit in pregnant women with the fetoplacental dysfunction with underlying preeclampsia.

\section{Conclusions and prospects for further development}

1. In the course of dopplerometry for women with preeclampsia on the background of the antihypertensive drugs intake (before the prescription of intravenous solution of pentoxifylline, arginine hydrochloride, levocarnitine and rheosorbilact), significantly $(p<0.05)$ increased $S / D, R I$ and $\mathrm{PI}$ indices in the umbilical and uterine arteries were revealed, which indicates the significant slowdown in the blood flow and the increase of vascular resistance in these structures.

2 . In the course of the proposed treatment, the restoration of the blood flow velocity and the stabilization of vascular resistance in uterine arteries and the umbilical artery were observed in the women of the main group. Improvement in the functional activity of the fetoplacental complex in women of the main group was manifested in a decrease in S / D in umbilical artery in 1.3 times, in the left uterine artery in 1.4 times and in the fetal aorta in 1,1 times; decrease in RI indices in the umbilical artery in 1.1 times, in the right uterine artery in 1.3 times, and increase in the middle cerebral artery in 1.4 times, despite the long-term intake of antihypertensive drugs.

3. Improvement of Doppler indices in the CG was not observed in the course of re-examination, which is indicative of the progression of the fetoplacental dysfunction in the course of the long-term intake of antihypertensive drugs for the treatment of preeclampsia.

4. The methodology is simple, effective, economically available and can be widely used in practical obstetrics.

Despite the fact that our conclusions are based on a small sample, the proposed method of treating fetoplacental dysfunction in women with preeclampsia seems promising and requires further research. The research of the possibility of using the above methodology in earlier gestational age and in the risk group for the prevention of preeclampsia is prospective and requires attention from scientists.

Comparative Physiology, 313, 395-399. DOI: 10.1152/ ajpregu.00245.2017

[2] Burton, G. J., \& Jauniaux, E. (2018). Pathophysiology of placental-derived fetal growth restriction. American Journal 
of Obstetrics and Gynecology, 218(2S), 745-761. doi: 10.1016/ j.ajog.2017.11.577.

[3] Efficacy and Safety of Rheosorbilact $₫$ Solution for Infusion, in a Complex Therapy of Peritonitis. (2019). Cochrane Central Register of Controlled Trials, 3, NCT03771170.

[4] Eremenko, A. A., Medvedeva, L. A., Minbolatova, N. M., \& Oistrakh, A. S. (2013). Эфрфективность реосорбилакта во время сердечно-сосудистой хирургии [The efficacy of the rheosorbilact during the cardiovascular surgery]. Хирургия (Моск.). - Khirurgiia (Mosk), 8, 59-66. PMID: 23996042

[5] Falco, M. L., Sivanathan, J., Laoreti, A., Thilaganathan, B., \& Khalil, A. (2017). Placental histopathology associated with pre-eclampsia: systematic review and meta-analysis. Ultrasound Obstetriks and Gynecology, 50(3), 295-301. DOI: 10.1002/uog.17494

[6] Griffin, M., Heazell, A. E. P., Chappell, L. C., Zhao, J., \& Lawlor, D. A. (2020). The ability of late pregnancy maternal tests to predict adverse pregnancy outcomes associated with placental dysfunction (specifically fetal growth restriction and pre-eclampsia): a protocol for a systematic review and metaanalysis of prognostic accuracy studies. Systematic Reviews, 9(1), 78. doi: 10.1186/s13643-020-01334-5

[7] Horbatiuk, O. H., Shatkovska, A. S., \& Hryhorenko, A. P. (2019). Патент на корисну модель № 132418 Україна, МПК А61K 31/00, A61P 15/00. Спосіб відновлення функції плаценти у вагітних жінок з фетоплацентарною дисфункцією на фоні прееклампсії [The patent for useful model № 132418 Ukraine, MPK A61K 31/00, A61P 15/00. A method of restoring of the placental function in pregnant women with fetoplacental dysfunction on the background of preeclampsia]. Biulleten, 4.

[8] Itani, N., Skeffington, K. L., Beck, C., \& Giussani, D. A. (2017). Sildenafil therapy for fetal cardiovascular dysfunction during hypoxic development: studies in the chick embryo. Journal of Physiology, 595(5), 1563-73. DOI: 10.1113/JP273393

[9] Jauniaux, E., \& Campbell, S. (1990). Fetal growth retardation with abnormal blood flows and placental sonographic lesions. Journal of Clinical Ultrasound, 18(3), 210-214. DOI: 10.1002/ jcu. 1870180315

[10] Jauniaux, E., \& Campbell, S. (1990). Ultrasonographic assessment of placental abnormalities. American Journal of Obstetrics and Gynecology, 163(5), 1650-1658. DOI: 10.1016/ 0002-9378(90)90645-N

[11] Lange, K. (2002). Mathematical and Statistical Methods for Genetic Analysis. (2th ed.). New York: Springer-Verlag. DOI 10.1007/978-0-387-21750-5

[12] Lauterbach, R., Rytlewski, K., Pawlik, D., Hurkala, J., Wojtowicz, A., Breborowicz, G., \& Szymankiewicz, M. (2012). Effect of Pentoxifylline, Administered in Preterm Labour, on the Foetal-Placental Circulation and Neonatal Outcome: A Randomized, Prospective Pilot Study. Basic \& Clinical Pharmacology \& Toxicology, 110(4), 342-346. doi:10.1111/ j.1742-7843.2011.00809.x

[13] Magee, L., \& von Dadelszen, P. (2013). Prevention and treatment of postpartum hypertension. Cochrane Database of Systematic Reviews, 4, CD004351. doi: 10.1002/ 14651858.CD004351.pub3

[14] Rytlewski, K., Olszanecki, R., Lauterbach, R., Grzyb, A., KiecWilk, B., Dembinska-Kiec, A., \& Basta, A. (2008). Effects of oral L-arginine on the pulsatility indices of umbilical artery and middle cerebral artery in preterm labor. European Journal of Obstetrics, Gynecology and Reproductive Biology, 138(1), 23-28. doi: 10.1016/j.ejogrb.2007.06.024

[15] Salmani, D., Purushothaman, S., Somashekara, S.C., Gnanagurudasan, E., Sumangaladevi, K, Harikishan, R., ... \& Venkateshwarareddy, M. (2014). Study of structural changes in placenta in pregnancy-induced hypertension. Journal of Natural Science, Biologycal and Medicine, 5(2), 352-355. doi: 10.4103/0976-9668.136182

[16] Safarova, S., Aliyeva, E., Abbasova, F., \& Mirzoyeva, K. (2020). Эффективность L-аргинина при плацентарной недостаточности [The Experience of L-Arginine Using in Placental Insufficiency]. Infusion \& Chemotherapy, 3.1, 67-68. DOI: 10.32902/2663-0338-2020-3.1-56

[17] Schoots, M. H., Gordijn, S. J., Scherjon, S. A., van Goor, H., \& Hillebrands, J. L. (2018). Oxidative stress in placental pathology. Placenta, 69, 153-161. DOI: 10.1016/ j.placenta.2018.03.003

[18] Sibley, C. P. (2017). Treating the dysfunctional placenta. Journal of Endocrinology, 234 (2), 81-97. doi: 10.1530/JOE-17-0185

[19] Suri, S., Muttukrishna, S., \& Jauniaux, E. (2013). 2D-Ultrasound and endocrinologic evaluation of placentation in early pregnancy and its relationship to fetal birthweight in normal pregnancies and pre-eclampsia. Placenta, 34(9), 745-750. DOI: 10.1016/j.placenta.2013.05.003

[20] Tomimatsu, T., Mimura, K., Endo, M., Kumasawa, K., \& Kimura, T. (2017). Pathophysiology of preeclampsia: an angiogenic imbalance and long-lasting systemic vascular dysfunction. Hypertension Research, 40(4), 305-310. DOI: 10.1038/ hr.2016.152

[21] Tomimatsu, T., Mimura, K., Matsuzaki, S., Endo, M., Kumasawa, K., \& Kimura, T. (2019). Preeclampsia: Maternal Systemic Vascular Disorder Caused by Generalized Endothelial Dysfunction Due to Placental Antiangiogenic Factors. International Journal of Molecular Science, 20(17), 4246. DOI: $10.3390 / \mathrm{ijms} 20174246$

[22] Tong, W., \& Giussani, D. A. (2019). Preeclampsia Link to Gestational Hypoxia. Journal of Developmental Origins of Health Disease, 10(3), 322-333. doi: 10.1017/ S204017441900014X

[23] Townsend, R., O'Brien, P., \& Khalil, A. (2016). Current best practice in the management of hypertensive disorders in pregnancy. Integrated Blood Pressure Control, 9, 79-94. doi: 10.2147/IBPC.S77344

[24] Vogel, J. P., Nardin, J. M., Dowswell, T., West, H. M., \& Oladapo, O. T. (2014). Combination of Tocolytic Agents for Inhibiting Preterm Labour. Cochrane Database of Systematic Reviews, 7, CD006169. DOI: 10.1002/14651858.CD006169.pub2

[25] Witter, F. R., \& Smith, R. V. (1985). The excretion of pentoxifylline and its metabolites into human breast milk. American Journal of Obstetrics and Gynecology, 151, 1094-1097. DOI: 10.1016/ 0002-9378(85)90391-6

[26] Zhao, Y., Zheng, Y., Liu, X., Luo, Q., Wu, D., Liu, X., \& Zou, L. (2018). Inhibiting trophoblast PAR-1 overexpression suppresses $\mathrm{sFIt}-1$-induced anti-angiogenesis and abnormal vascular remodeling: a possible therapeutic approach for preeclampsia. Molecular Human Reproduction, 24(3), 158169. doi: $10.1093 / \mathrm{molehr} / g a x 068$

\section{ЗАСТОСУВАННЯ РОЗЧИНІВ ПЕНТОКСИФІЛІНУ, АРГІНІНУ ГІДРОХЛОРИДУ, ЛЕВОКАРНІТИНУ І РЕОСОРБЛАКТУ ДЛЯ} КОРЕКЦІЇ ФЕТОПЛАЦЕНТАРНОЇ ДИСФУНКЦІЇ У ВАГІТНИХ ЖІНОК 3 ПРЕЕКЛАМПСІЄЮ

Горбатюк О. Г., Григоренко А. П., Шатковська А.С., Біньковська А. М., Васьків О.В., Герич О. Х., Гарбузюк В. В., Ропотан А. Г.

Анотація. На сьогоднішній день не існує ефективних методів лікування феетоплацентарної дисфункції (ФПД) у вагітних жінок з прееклампсією. Метою дослідження було вивчення запропонованого авторами методу відновлення ффункціональної активності фретоплацентарного комплексу у вагітних жінок з ФПД на фоні отримуваного лікування прееклампсії. Було 
проведено рандомізоване контрольоване дослідження ефективності запропонованого методу лікування (внутрішньовенного розчину пентоксифріліну, розчину, що містить аргінін гідрохлорид, левокарнітин та реосорбілакт) у 37 вагітних жінок в терміні 35-40 тижнів вагітності із ФПД на тлі помірної прееклампсії. Досліджували такі ультразвукові доплерометричні показники: S/D (систоло-діастолічне співвідношення), RI (індекс резистентності), PI (пульсаційний індекс) в артеріях пуповини, правій та лівій маткових артеріях, середній мозковій артерії плода, внутрішній сонній артерії плода та аорті плода до та після запропонованого лікування. Cmamucmuчні дані обробляли за допомогою LibreOffice Calc (Mozilla Public License v 2.0), пристосованої для медичних та біологічних досліджень. Використовували непараметричні критерії Вілкоксона, критерії Манна-Уітні при рівні значущості р<0,05. Після проведеного лікування у жінок основної групи спостерігали стабілізацію фетоплацентарного кровообігу, що проявлялось у зниженні S/D в артерії пуповини в 1,3 рази, у лівій матковій артерії - в 1,4 рази та в аорті плода - в 1,1 рази, а також зниженні показників RI в артерії пуповини - в 1,1 рази, у правій матковій артерії - в 1,3 рази та підвищенні в 1,4 рази - в середній мозковій артерії. Отже, при використанні запропонованого лікування у жінок основної групи спостерігали відновлення швидкості кровоплину та стабілізацію судинного опору у маткових артеріях та артерії пуповини. Дослідження можливості використання вище описаної методики у більш ранніх термінах вагітності та у групі ризику для профрілактики прееклампсії є перспективним і потребує подальшої уваги. ключові слова: фетоплацентарна дисфункція, прееклампсія, лікування. 